\title{
」.ザイマンのアカデミック科学モデル
}

\section{J. Ziman's Model on Academic Science}

\author{
三宅 苞 ${ }^{1}$ \\ ${ }^{1} \mathrm{Ph} . \mathrm{D}$. (科学技術社会論) 社会技術研究システム システム研究センター \\ (E-mail: miyake@ ristex.jst.go.jp)
}

\begin{abstract}
」.ザイマンは、1960 年代より金属物理学の研究を進める傍ら、科学者共同体による知識生産という視 点から数多くの科学論の書を著し、この分野でも注目されてきた。しかし、日本においては、これまで幾 つかの訳書はあったものの、弚の科学論についての詳細な検討はなされてこなかった。本論は、『パブリッ ク・ノレッジ』から最近の『リアル・サイエンス』までの主要著書を採り上げ、比較検討し、ザイマンの 思考の変遷を明かにする。特に、ザイマン科学論の特徽であるアカデミック科学のモデル化とポスト・ア カデミック科学批判について考察する。さらに、ザイマンの欧米での最近の論評に注目し、日本の科学論 の中での展開可能性を探る。
\end{abstract}

キーワード : 科学論, 合意, 科学者共同体，モード論，アカデミック科学，知識生産、エトス、 規範、マートン、産業科学

\section{1 . はじめに}

ジョン・ザイマン (John Ziman) は、1925 年イギリス に生まれ、オックスフォード大学に学び、オックスフォ ード、ケンブリッジ大学の講師、研究員を経て、1964 年 から 1982 年までブリストル大学の理論物理学の教授を 務めた。关の間、液体金属の理論的研究て国際的な業績 を挙げ、1967 年には「金属の電気的特性」の研究により 王立協会会員に推挙された ( 」.ザイマンの近影を Fig. 1 に記す)。

また専門分野での研究の傍ら、科学の社会学、教育、 認識論など科学のメタ・レヴェルの問題にも関心を向け るようになつた。科学と社会のための会議」の議長を長 年務め、1986 年から 91 年までは「科学技術政策支援グ ループ」の代表も務めた。また『パブリック・ノレッジ』 (1968)から近著『リアル・サイエンス』(2000)まて科学者 共同体をべースにした独自の科学論を発表してきた。こ のようにザイマンは、欧米の科学界において、科学政策、

科学教育、あるいは科学論において少なから影響を与 えてきた。

一方、わか国においては、光の著作のいくつかは邦訳 され、さらに 2002 年には「社会技術研究フォーラム」の

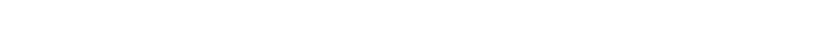
論についての詳しい論評は日本においてはまだなされて (ない2)。光の一因は、内部観察に基づくザイマンの科 学論は、科学哲学の流れの中て扱いにくい対象なのかも しれないし ${ }^{3)}$ 、ザイマンと同じ現場の研究者は、あえて この分野て論を起こさないからかもしれない。しかし、
ザイマンの科学論は、日本において基礎研究を含めた科 学研究のありかたを論ずる上で、極めて有益な知見を与 えるものと考えられる。

本論は、ザイマンの科学論の正確な把握と、現代科学 論の中での光の展開を目的とする。まず第2章でザイマ ンの主要な科学論四つを採り上げ、乥れ光れについて比 較検討を加える。第3章でザイマンの科学知識の生成モ デルを「ザイマン・モデル」として描出する。第4章で は、弚のザイマン・モデルの欧米での展開を確忍した後、 日本における科学論、特に科学者共同体の議論への適用 を試みる。

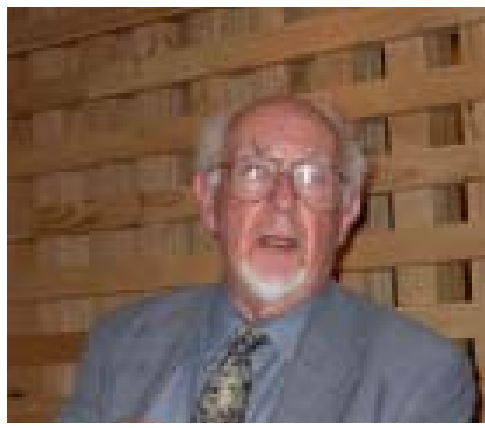

Fig. 1 」.ザイマン近影 ${ }^{4)}$

\section{2. ザイマンの科学論}

ザイマンはこれまで10冊の科学論関係の単著を表して (る。このうち一般向(の科学社会史が1 冊 $^{5)}$ 、科学論の

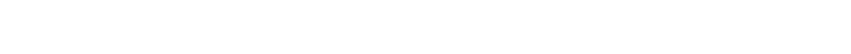


か科学知識論であるが、本論ではこのうち 2 編は割愛し9), 10)、残りの4冊につい年代順に検討を行う。

\section{1 『パブリック・ノレッジ』(1968) ${ }^{11)}$}

ザイマンは前述したように 1964 年にブリストル大学教 授に着任し金属物理学の研究を発展させていくが、すでに その頃から「科学とは何か」にも興味を持つようになって (る12)。

ここで、1960年代前半までの主要な科学論について簡単 に触れておく。演繹と帰納の厳密な言語的手続きに科学論 の本質があるとする R カルナップ、 O.ノイラートらの論 理実証主義は、1920４0年にかけて興隆し、すでに中心的 な科学論になっていた。一方、科学理論の本質は反証可能 性にかるとするK.ポパーの『科学的発見の論理』が1935 年に著された。「君はクーン病にかかったか」という挨拶言 葉を生んだほどの T. クーンの『科学革命と光の構造』は 1962年に出版された。クーンの主張の一つであるパラダイ 么間の共役不可能性に関しては、ザイマンの一時期の同僚 であった N R.ハンソンが科学的発見のパターン』(1957) ですでに言及していた。またザイマンと同じく科学者のM. ポランニーは、『個人的知識』（1958）において、主観的な知 識のもつ客観性について論じた。また1960年代には、W 八 グストロームら歴史家や社会学者による「科学の社会学」 カ盛んになってきた。

このうち論理実証主義者やポパーらの哲学的アプローチ に対しては、ザイマンは「白か黑かはっきりしすぎる論で ある」と批判的であった ${ }^{13)}$ 。しかし、『ハブリック・ノレ ツジ』をザイマンに書かしめた直接の動機は、「科学の社会 学」への違和感であつた。乥れは、手帖とテープレコーダ 一を携えてヨーロッパの大人が中国人の家庭に入り込んで 具いをかぎだ光うとする」程度のものであり、乥れでは「あ まり書かれない、語られない、しかし光れ自身の規則に従 っている」科学者共同体の世界を捉えることは困難である、 とザイマンは思ったのである。

その第1章「科学とは何か」では、科学て扱われる推論 は、日常の注意深し議論とあまり変わらない」と、科学と 日常の結びつきがます確忍される。光の上で、科学は以下 の意味で「公的な (public) な知識」であると特徵付けら れる。

[科学の]事実や推論は一定期間の他の有能で公平無私なあ 個人たちによる批判的考察やテストに一定期間生き長らえ、 弚れがほとんど普遍的に受け入れられるほどに説得的であ ることか理解されなければならない。科学の目的は単なる情 報の潗でもなければ無矛盾な概念の発表でもない。光れは 最も広い可能性をもつ分野における合理的意見のコンセン サスにある。14)
「他の有用で公平無私な個人」よる「批判的な考察やテ ス卜」によって、最終的に客観的な知識となっていくとい うこの知識形成論は、『リアル・サイエンス』までを貫くザ イマンの科学論の基本である。

第2章では、このコンセンサスを基準にして知的に「姉 妹的学科」である、法学、哲学、歴史、技術 (Technol ogy)、 “社会科学” か犐学と異なることか論じられる。特に、技 術に対しては

技術者は利用可能な知識すへててを使って最善をつくさね ばならない。彼が爫の問題に理想的な解決を計算するには光 の知識はいつも不十分である。光して乥れを得るためのすべ ての研究かなされるのを待ってはいられない。15)

このように知識の生産と利用という違いによって、科学 と技術力区別される。と同時に、科学知識の応用性、特に その「負の側面」への言及がザイマンの科学論からはほと んと抜け落ちることになる。これもザイマンの科学論の大 きな特徵である。

第3章は、科学者が自らの研究に用いる方法や概念につ いてである。これは、次著『リライアブル・ノレッジ』に おいて地図の比喻とともにより詳細に論述される。クーン のパラダイム論は概ね肯定的に論じられるが、科学革命を 政治革命に結びつけすぎている点か批判される ${ }^{16) 。 ~}$

第4章は、科学の教育についてであり、研究を実行する ことによって教師は謙虚になり、非ドグマ的になる」と研 究と教育の関連性力強調される ${ }^{17)}$ 。

第5章の「個々の科学者」では、制度としての科学の社 会力論じられる。科学者共同体の規範 (エトス) がここで 一寸採り上げられ、マートン規範 ${ }^{18)}$ も光の一つとして簡 単に紹介される。ザイマンはマートン規範の中でしばしば 論じられるが、彼自身はマートン規範から出発したのでは ないのである。

第6章の「コミュニティとコミュニケーション」では、 学会誌への発表と優先性、レフリーの役割と受容力詳細に 論じられる。レフリーの役割は強調されるものの、光れは 厳しい審査機関ではない。

レフリーはすべてのエラーを防ぐことを期待されている のてはない。彼の役目は光の論文が注目に值すると確証する ことなのだ。… 今のコンセンサスを摇るがすような新しい アイテアアができるだけ正確に明解にもつとうまく表現され るようにと主張するのだ。19)

もちろん、ザイマンは、同僚審査か新しい知の発見を無 視した例、拒絶した例については十分知っている。光の上 で、このようなレフリーの柔軟性、寛容性を、むしろ規範 として勧めているのである。 
第7章は、制度と個別の権威についてであるが、どのよ うな制度であっても個人の自由な言論を許すような制度で あるべきであり、ドグマに囚われること、研究機関や学者 か潅威化されることの危険性などか指摘される。

『パブリック・ノレッジ』では、このように、ザイマン の科学モデルの原型力提出される。光して光れは 10年後の

『リライアブル・ノレッジ』で、認識論からの補強により より詳細なモデルとなる。

\section{2 『リライアブル・ノレッジ』(1978) ${ }^{20)}$}

第1章では、科学が「信頼できる( rel i able)」ことを本 書のテーマにした理由が述べられる。光れは「科学技術に よって生み出された事物の中には人間に害を与えるものも あり」、弚のため「科学が・・多方面から攻撃にさらされ るようになった」からである21)。弚れに対しザイマンは、

「科学は何を語りかけているか」 - 何を作っているか ではなく - という科学の認識的面から信頼回復を行な おうとする。

第2章では、科学は「最高の合意をめざす」ものである から、科学者間でのコミュニケーションには「あいましさ」 があってはならず、弚のための手段として数学、比喻、モ デルなどを使う必要性力論じられる。

第3章ては、光のコミュニケーションの前段階、すなわ ち、研究の出発点である「ものを見る」ことに立ち返る。 弚れは紛れもない個人の主観的行為であるが、同時に、他 の人も同じように見るであろうという「共通主観的」なも のであることか論じられる。すなわち、日常生活でものを 見ること自体がすでにコミュニケーションの要素をもって いるのである。また、観察に伴う誤差や、実験機器の使用 の意味、科学の巨大化についても触れている。

第4章で、科学的知識か世界地図、あるいは、世界像に 比喻される。

科学的知諳はまるでくもの巣のように、法則、モデル、理 論上の原理、公式、仮説、解釈などのネットワークとなって おり、しかも光のネットワークは全体としていかなる個々の 構成要素よりはるかに強力となるようきわめてち密に織り 込まれている。221

もちろん、ザイマン自身が引用しているように、科学的 知識を地図て喻えることは、ポラニー、クーン、トゥール ミン他の何人かがすでに行っている23)。しかしザイマンほ ど地図に引きつけた論者はいない。光の意味で、地図の意 味を知ることは、ザイマン理解には不可欠である。

第1に、地図は描くことができる対象、すなわち、客 観的世界の存在を前提としている ${ }^{24)}$ 。第2に、光れ光れ の地図はネットワーク的に関連している。地図は細部に おいて正確でなければならないと同時に、樣々な地図は
相互に整合的である。第3に、地図は、生活の案内役と なる。生活者は地図を頼りに誤りのない行動を起こすこ とか出来る。第4に、地図には新しい発見か泇わるのみ ならず、時に表現方法や視点の変革もなされる。

科学知識もこのような特徵をもつ。この第 2 点と第 4 点を結びつけると、地図としての科学的知識は結果的に は科学者共同体の手を離れ、一個の有機的な存在という イメージを与えられることになる。この有機的イメージ は、後の『リアル・サイエンス』て提出されることにな る。

第5章では、害在の世界」に対象を移し、乥のリアリ ティか論じられる。しかし、実在高のものの哲学的存在 論ではなく、人間の知覚の側での議論である。「科学は基 本的に人間の知覚能力」に依存していることか確忍され、 弚の能力の発達を理解するには、「关の人の幼照時代に遡 る必要がある」と、ピアジェの発達心理学力湲用される。

第6章の「科学の世界」では、個々の科学者によって 報告される矛盾に充ちたメッセージ」か犐学者共同体に よる批判的選択によって客観的知識となっていく、光の 過程力論じられる。

ここで科学者は社会の「代理人」と見なされている。 すなわち、科学者は本質的に日常生活のパラダイムにと どまるゆえに、“すべての理性的人間” の代理人として正 当性を与えられている」のである。

また「科学弚れ自体は絶えず、科学者たちが創出し共 有するような新しい世界像、すなわち新しい局面を組織 化していく原理となり光う“主題”を生みだす」と述べ ている。ここに、科学に対する過程論的な見方を伺うこ とができる。なぜなら、科学自体が光うした主題を絶え ず「生み出していくなら」なら、科学研究は、見えざる 手によって導かれる、永遠に終わることのない営みとな るからである。この視点から興棎いのは、市川の科学 論との比較である ${ }^{25)}$

第7の「社会的知識」は、社会心理学、社会学、人類 学、経济学など人「間の行動」についての知識である。 乥れらが合意ある知識となりうるかか検証されるが、 結局「行動についての合意可能性は論理学的な思考や知 覚の合意可能性に比べて、不完全であり、欠点も多い」 とされ、従って、「科学的知識」としては認めにくいと判 断される。

以上のように、『リライアブル・ノレッジ』では、科学 知識生成力認識論的側面から詳細に論じられる。しかし、 マートン規範についての記述は、本書でもわずかである。

\section{3.『縛られたプロメテウス』(1994) 26)}

『パブリック・ノレッジ』(1968) から 26年後に『縛られ たプロメテウス』(以下『プロメテウス』と略記) カ出版さ れる。本書のテーマは「ここ30年の間」に科学の世界に起 
きた「急激で後戻りのできない構造変化」すなわち、国の 予算をこれ以上要求できない「縛られた」状態の中でなお も驚くべき進歩を生み出しつつある科学についてである。

特に、一定資金額の中での研究費の配分をめぐって、資 金提供者の側では、科学政策の戦略が重要になり、また優 先順位をつけ、評価することが重荷になってきたこと、研 究者の側では、予算獲得、弚のための申請手続きか煩杂隹な 仕事となり、資金提供者 (顧客) との関係揳約的になっ ていきたことか論じられる。ザイマンの記述は、研究者と 管理者の立場を何度も変えながら、この資金配分がもたら した新しい状況の利害得失をさまざまに記述する。炎の立 場を幾度も変えての記述は、研究者と研究管理者に相手の 立場を理解させることにおいて極めて説得的である。

この30年の変化は、科学者の行動規範の上では、マー トンの規範 ( C UDOS) から、新しい原則 ( P L A C $E$ ）への移行として捉えられる。すなわち、公有主義 (Communalism)、普遍主義 (Universalism)、無私性 (Disinterestedness)、独創性 (Originality)、懷疑主義 (Scepticism) から、所有的(Propri et ary)、局所的( Local )、 権威主義的( Aut hor i t ar i an)、請負的( Conmn ssi oned)、専 門的(Expert)な仕事への移行である。

この移行の議論は、本書の後半の第7章に初めて表れ る。光してCUDOSとPLAＣＥの樣々な特徽力比較 された後、科学知識の進歩のための基本要素」としての C U D O S世界の確忍でもって本書は終わる。このCU D O Sの確認ニ乥本書の最大のメーセージであったと思 われるが、弚れは、女性宇宙飛行士の30年ぶりの地球 生還というS F的な華やいだ冒頭での語りや、乥れに続 く樣々な構造変化の記述に隠れて、充分に伝わってこな い。

同じ頃、ギボンズらが『新しい知識生産』(1994) にお いて、同樣の変化をモードの変化として肯定的に捉えた 27)。光してこちらの方が少なくとも日本においては注目

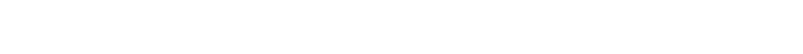
しかし、『リライアブル・ノレッジ』までのザイマンの議 論を踏まえて、注意深く『プロメテウス』を読めば、ザ イマンの関心は、ギボンズらと異なって、変化という事 実よりもむしろ关れがもたらす弊害に向けられているこ とか解るはずである。

\section{4. 『リアル・サイエンス』(2000 ${ }^{30)}$}

『リアル・サイエンス』のテーマは『プロメテウス』 と同じくここ 30 年間に起きた科学界で変化であるが、 弚れがより明確な概念でもつて論じられる。すなわち「ア カデミック科学」から「ポスト・アカデミック科学」へ の変化と、弚れ光れの科学における「マートン規範」の 確認と逸脱についてである。

第1章では、「科学とは何か」の問いに対して、乥れ
は「知識生産を第一の目的とする特定の多くの人々を含 む、ある社会制度である」と従来のザイマンの定義か確 認される。

第2章では、光の科学の特徵を抽出するためフレーム か絞られていって、純粋科学 (あるいは基礎科学) に到 るが、より適切な用語として「アカデミック科学」か採 用される。

純粋科学は、科学一般と同じく自然に認識できるものであ る。乥れを抽象的に規定するのてなく、弚の存在体に注目し よう。この言葉を使うとき心に浮から゙のは、よく知られたあ の特徵的な活動、すなわち、アカデミック科学である。311

产れは、「1850 年代から 1960 年代」にかけて大学なら びに「大規模な政府や企業の研究開発機関」でなされた 純粋科学の研究活動である。

第3章では、光のアカデミック科学を一つの社会的制 度として保つものは「語られない規則」であるとし、乥 の規則の要素として、マートン規範、すなわちＣＵＤ０ S力採り上げられる。なぜなら光の規範は「個々の科学 者の 科学的意識 の中にエトスとして組み込まれてい る」からである。すなわち、乥れは科学者共同体の中に 観察される事柄である。

第4章の「知識生産の新しいモード」では、「ポスト . アカデミック科学」か論じられる。すなわち、アカデミ ック科学は、「ここ 2,30 年想像も出来なかつた新しい特 徵を獲得し、ポスト・アカデミック科学」に道を譲つた」 のである。炎の新しい特徵は、「科学の集団化、研究資金 の限界、応用・目的志向、産業化、管理強化など」であ る。ここで「産業化」に特に注意力执われ、光れを説明 するため「産業科学 (industrial science)」という用語力持 ち出される。

産業科学は典型的には、1960 年代までに巨大企業や少数 の国の軍事研究機関の科学技術者の研究方法において発達 したものとなっていた。弚れは知識生産というよりむしろ組 織性において特徵つけられる。32)

アカデミック科学と産業科学は互いに影響を及ぼしな がら、光れ光れポスト・アカデミック科学、ポスト産業 科学に移行している。ただし両者は区別される。これら の関係は Fig. 2 のように図示される。なお、ギボンズら の「モード2科学」は、「アカデミック科学と産業科学の ポスト産業的なハイブリッド」 ${ }^{33)}$ と、ポスト産業科学 に近いものと見なされる。したがってモード2科学は、 しばしば登場するものの、議論には積極的には取り入れ られていない。

第5章から9章までは、光れにC・U・D・O・ 
Sが当てはめられる。光れ光れの章において、アカデミ ック科学におけるマートン規範の維持か確忍され（光れ からの逸脱例も数多(紹介されるものの)、一方、ポス ト・アカデミック科学でのマートン規範からのずれか洌 挙され、批判される。

(場所） (以前)

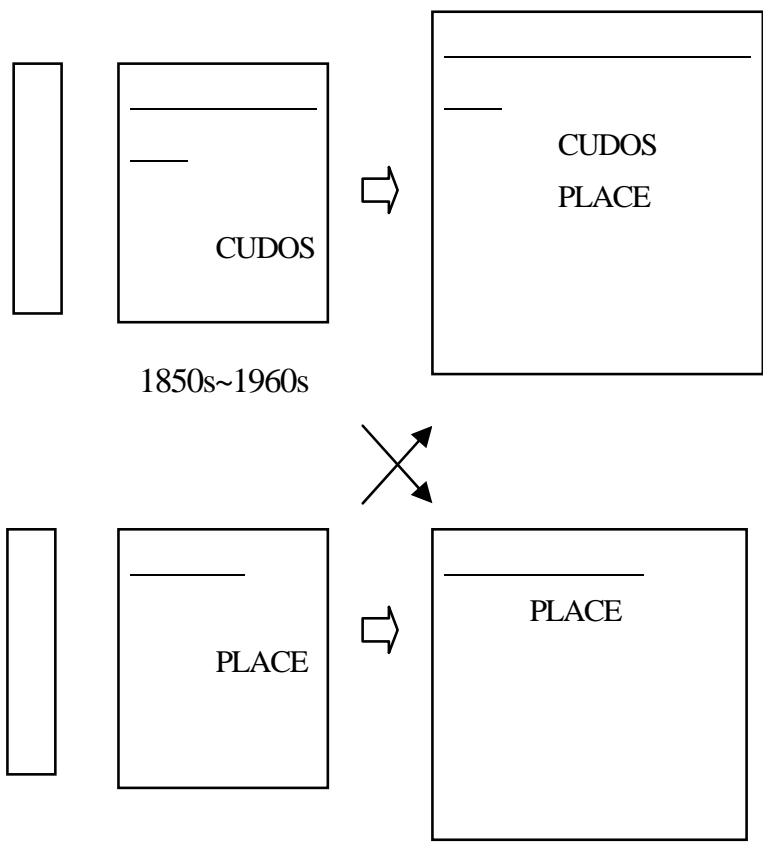

( 1960s)

Fig. 2 科学生産の变化

まず第5章の「コミュニティとコミュニケーション」 では、アカデミック科学においては、間主観的な観察が 科学者共同体でのコミュによって公的な知識になること カ説明される。一方、ポスト・アカデミック科学は「知 識は所有的になり、非公開的になり、公開後も容易に修 正される」などの点て批判される。

第6章は「普遍性(universalism)と統一化」であるが、 マートンの非人種的差別という意味で普遍性ではない。 ザイマンは、乥れを科学的手法の理論性、分類的性格と 統一性、地図への比喻性の意味使っている。ここでのポ スト・アカデミック科学はない。

第7章の「公平さ(Disinterestedness)と客観性」は第5章 に内容的に近く、個人的な観察がかにして客観的な知 識になりうるかか問われる。ここで「公平さ」とは、「非 自己目的な追求」の意味であり、したがって「研究を特 定の社会的関心に向けること」は戒められる。

一方、ポスト・アカデミック科学では、この公平さが 失われ」「研究コミュニティの見えざる手から離れ、政 策と利益の支配下に置かれる」と、厳しく批判される。

第8章の「独創性と創造性」では、アカデミック科学
のこの二つの特色が、科学者か洪有する地図の中でどう 生まれるかか論じられる。また前 7 章とも関連するが、 問題設定の社会からの自律か強調される。「アカデミック 科学では、研究課題は光れ自身の研究の中から生まれる」 のであって、特定の社会的関心からではないのである。

一方、問題設定に社会的責任を促す」ポスト・アカデ ミック科学は、もつと利益あるように使われる知識を生 まないであろう」と批判される。この問題設定の独立性 においてザイマンは、知識生産を応用的文脈に移行させ ようとするギボンズらとは大きく異なるのである。

第9章の「懷疑性と知識の成長」では、同僚審査によ る組織化された懷疑の重要性力論じられる。ポスト・ア カデミック科学は、光のシステマティックな知識の品質 管理において批判される。すなわち、科学者にとってポ スト・アカデミック科学に従事することは、光の言説を 変化させることなのである。

興味あることに、科学知識はここで、ポパーの第二、

第三知識として位置つけられている。すなわち、科学 の蔵に入っているものは、シンボリックな代表を含む第 二世界の知識であり、完全な客観性は持ち得ないとしつ つも、弚の求める方向性において第三世界力想定されて いる。ここにもザイマンの科学観がよく現れている。

もう一点注目すべきは、科学知識の進化に関する議論 である。ザイマンのいう知識力洧機的存在であることは、 先に触れたが、ここで、知識は、B V S R (Blind Variation and Selective Retention: 盲目的選択と選択的存続) によっ て自身が進化的に成長するものとして論じられる。

科学ば 盲目的”な変化と選択的な引き留め (B V S R ) による前進的て終わることのないサイクリックなプロセス である。…科学知識は生きている有機体の多樣な子孫と同 じく、“盲目的に”生産され、弚れらの見かけの“適正さ” の予見によらずして、乥の後の“選択”すなわち、批判的環 境と知識庫ての再生産における差別的な“生き残り”によっ て決定されるのである。 ${ }^{34}$

アカデミック科学の多くの性質、たとえば、無䭾な効 用、企てられた中立性、などはこの進化論によってうま 〈説明される ${ }^{35)}$ 。一方、ポスト・アカデミック科学は「社 会・経済的ファクター、遂行性、契約的精査などは $\mathrm{B} V$ S Rモデルに含まれていない、生物的アナロジーはない」 などの理由で進化論的に扱えないとされる。

第 10 章の「では我々に何か信じられるか」では、これ まで述べてきたアカデミック科学が、もとの大きなフレ 一ム、すなわち、フッサールの「生活世界の知識」36) に引き戻される。アカデミック科学は「人間の生活世界 と対処するための知能の道具」であり、人間の行動を動 機付ける有益で強力な信仰体系」であることか沶される。 
そして、ポスト・アカデミックの科学者も「彼ら自身の 個人的発見の誤りをなく光うと、また他者の主張の受容 において十分用心深くあろうと努めている」と、CUD O Sのエトスを継承する現場科学者の確忍て結ばれる。

ザイマンは、本書においても(『プロメテウス』と同樣 に)、アカデミック科学の復権を実現化するための具体的 方針は提示していない。弚れは本書力終わつたところか ら始まるザイマン自身を含めた科学論者の作業であろう。

\section{3. ザイマンのアカデミック科学モデル}

以上、ザイマンの科学論について検討を行ってきた。 『パブリック・ノレッジ』てはまず科学者共同体による 知識生産という基本モデルか提示され、『リライアブル ・ ノレッジ』において、認識論、地図という比喻の導入な どによってモデルの精密化か溷られた。『プロメテウス』 では、光の科学者共同体にここ 30 年ほどに起きている構 造変化か採り上げられ、マートン規範からの逸脱力懸念 された。『リアル・サイエンス』で以上の議論か流合され、 アカデミック科学とポスト・アカデミック科学がマート ン規範の維持と逸脱において対比的に論じられた。

このようにザイマンの科学論は、結局、アカデミック 科学モデル (以下「ザイマン・モデル」と記する) の提 示と、ポスト・アカデミック科学の批判に要約される。 弚のうち後者は前者をもとにしての批判であり、したが って前者がより重要である。ザイマン・モデルは以下の 要素からなる。

1. 科学観察の日常性 :

科学者は、ある問題について光れを理解しようとして、 観察する。炎の視覚的判断は我々の日常行動の延長であ り、乥れは各人の成長の過程で学んた間主観的な能力に 依拠する。科学者は光の意味で社会一般の代表者である。 2 . 科学者共同体内での問題設定 :

選択される問題は、科学者共同体の中で関心事、本 人の好奇心、競争心などの文脈において決定される。特 定の社会的関心傾注は戒められる。

3 . 科学者共同体による精査と批判:

科学者は光の観察を理論、数值、モデル、パターンを 使って理解し、論文としてまとめて科学者共同体の同僚 に公表する。マートン規範を共有する同僚は、合意をめ ざして乥れについての批判と吟味を行う。

4. 科学者共同体を結びつけるマートン規範 :

科学者共同体を結びつけて、同僚への懷疑と受け入れ に向かわせるものがマートン規範、すなわち、公有主義 (Communalism)、普遍主義 (Universalism)、無私性 (Disinterestedness)、独創性 (Originality)、懷疑主義 (Scepticism)である。
5 . 完全性へ向かって進化する科学知識 :

科学者共同体によって合意されたものは、知識の藏の 中にネットワーク的に蓄えられる。光の知識ネットワー ク自体は、進化する一つの有機体としてみることができ る。

6 . 生活を導く科学知識 :

このように科学者共同体という専門家によって保証さ れた知識であるから、人々は信頼して光れを日常生活の ために使う事か泏来る。

第6項は、1項に戻って一つのサイクルをなす。ザイ マン・モデルはFig. 3のように表現される37)。

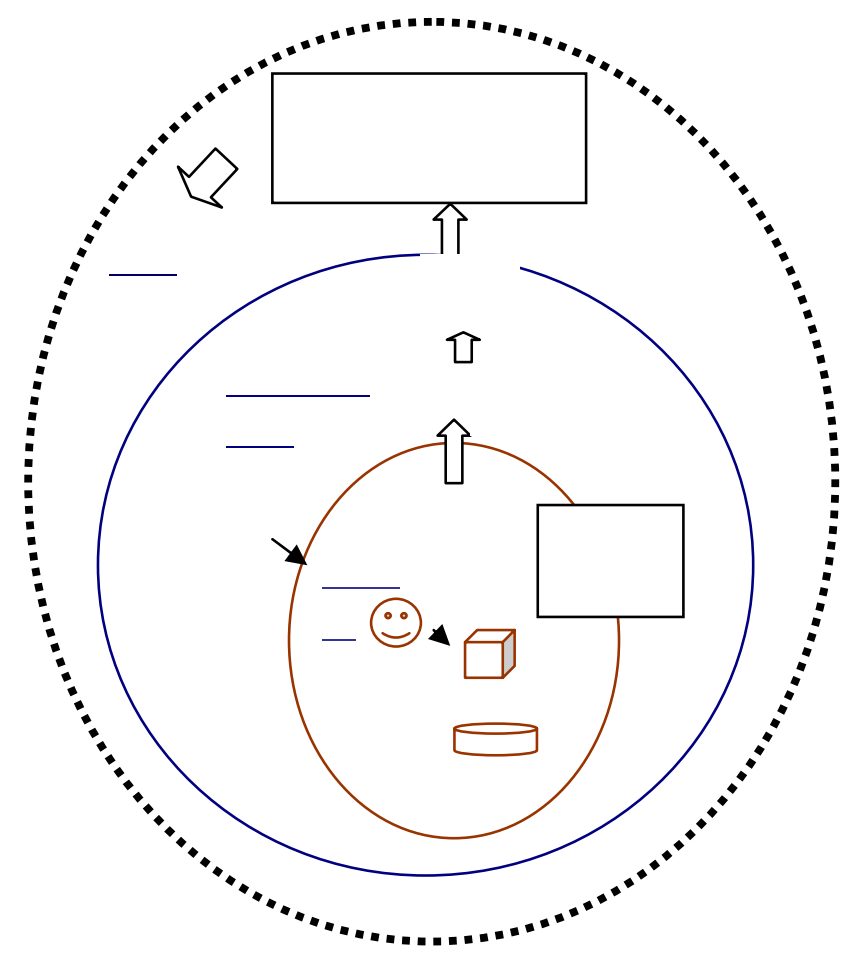

Fig. 3 ザイマンのアカデミック科学モデル

1960 年代までの「良き科学」であるアカデミック科学 をザイマンはこのようにモデル化した。このザイマン・ モデルはいかに論じられるべきであろうか。まず、この モデル自身の検証が考えられる。すなわち、ザイマン・ モデルがはたして 1960 年代までのアカデミック科学を 説明するモデルであるかどうかの検討である。关れは第 一にザイマンと同じく科学者によってなされるべきもの であろうが、しかしいままでのところ、弚れについての 彼らからの批判は現れていないようである。一方、文献 20)での桜井の解説にあるように、現場の科学者からの支 持は少ないながらも確認できる。

よって、このモデルの妥当性を認めて、これを「道具 的科学」も含めた現代の科学研究のあり方に適用するこ とか洧効な議論の方向であろう。乥の場合、もちろん全 面的適用は不可能であろう。特に、第2 項の「科学者共 
同体内での問題設定」は、 21 世紀の「社会のための科学」 の中では限定的に扱われるべきである。しかし、上記第 3項の「科学者共同体による精査と批判」は、注目され るべきである。ここにおいて「はじめ 90 \%の誤りをも つた最初の論文内容も、90\%の真実性を持つことにな る」からである。乥れは道具的・非道具的を問わず、こ れからの科学研究にも積極的に取り入れられるべき要素 ではなろうか。

\section{4 . ザイマン・モデルの展開}

\section{1.欧米の場合}

ザイマンについての欧米で議論も、多くは、光の方 向にむかっているようである。光の中で最も目に付くの は、『科学 : 伝統, アカデミックまたポスト・アカデミッ ク科学？』のフーカー(C. A. Hooker) である ${ }^{38)}$ 。フーカ 一は「我々が必要としている科学知識の具体化された理 論を非常な成功をもってザイマンか提出した」と、『リア ル・サイエンス』を高く評価する。光の上で、ザイマン は「読者の期待にも拘わらずポスト・アカデミック科学 に対してＣＵＤＯＳ以外の規範を提示していない」こと を指摘し、乥れを補うものとして「制度設計、規範間の 緊張、自己学習としての認識」等を提案している。ダル ガード (T. Dalgaad) らは、まず農業環境科学において、 C U D O Sの多くか慟いていることを確認し、光の上で 新しい方向性を模索している39)。ハンセン ( T. B. Hansen) は、C U D O SとP L A C E を検討した上で 光れらを越えた新しい科学研究のあり方である「草の根 研究」を提案している40)。エルノ・キョールヘーデ( E. Erno-Kjolhede)は、 C U D O Sと P L A C Eの規範の双方 の重要性を研究管理論の中で展開している ${ }^{41)}$ 。

また、ザイマンへの直接の言及はないが、ソナート $(\mathrm{G}$ Sonnert）らは、アメリカにおけるこれからの基礎研究の 在り方として、「ジェファーソン型」(社会目的のための 基礎科学研究) を提唱している。アカデミック科学の価 值を認める点で立場を同じくするものといえよう ${ }^{42)}$ 。

一方、ザイマンのアカデミック科学に最も批判的なの は、モード論のギボンズらである。『科学を再考する』4 3)において、ギボンズらは、いまや社会と科学は「モー ド 2社会」へ向かって共進化的に変化しつつあると論じ る。モード 2 社会では、科学を含めた知識は「アゴラ」 と彼らか呼う洺樣な参加者なる広場の中て樣々に議論さ れることにより「ロバスト (頑強に)」になるとされる。 第 11 章、弚の名も「リライアブル・ノレッジからソー シャリー・ロバスト・ノレッジへ」において、ザイマン のいう「特定の同僚グループ内の固く結ばれたコミュニ ティで一致された知識」は限られた信頼性しかない、閉
鎖的なアカデミック科学では知識」は頑強ではあり得な いと強く批判される。

ギボンズらのモード 2 社会は、社会のための科学」と いう2 1世紀の科学の大きな゙流れのなかで、非常に説得 的である。しかし、多樣な参加者か昿い場て議論するこ とになれば、科学的案件についての合意は一層困難にな ろう。ザイマンが示した合意モデル (Fig.. 3) を越える べき合意のためのモデルを、ギボンズらはまだ提出して ないようである。

\section{2. 我力国の場合}

わか国においては、冒頭て述へたように、ザイマン・ モデルについての論評も展開もほとんどなされていない。 引用1) を除いては、藤村によるC U D O Sに重心を置 いた『プロメテウス』の解釈 ${ }^{44)}$ と、増田による『リア ル・サイエンス』の紹介 ${ }^{45)}$ がある程度である。しかし、 ザイマン・モデルは、わか国での科学研究のあり方につ いての議論に極めて有効な論点を提供するものである。 科学者共同体についての議論は、科学技術社会論 (以 下S T S と記す) において盛んである。論者によって視 点や方向性の違いはあるものの、弚の主要な議論は、専 門家による知識の不完全性の指摘し、光れを市民側から の科学への参加、あるいは、専門家と非専門家の協同な どで補うというものである ${ }^{46) 。}$ 乥こでは、専門家と非専 門家力明確に区別され、しばしは後者の知識の摇れや非 社会性が非難される。

しかし、ザイマン・モデルから見れば、炎のような区 別は意味がく、科学知識力摇れることも - 一致は めざすのであるが - 当然なのである。 S T S か溥門 家との協働を呼びかけるのであれば、光の議論のなかに もつとザイマン・モデルを繰り入れる必要があるのでは かろうか。すくなくとも光のほうが、科学者からは受け 容れやすし議論となるだろう。

次に「科学者の新しい役割」を、科学者共同体、特に 日本学術会議に求める吉川弘之の議論が注目される ${ }^{47) 。 ~}$ 吉川は、「我力国において未成熟なアカデミーの機能を、 科学者自身が創出することか緊急の課題である」とする。 产の課題に応えるものとして吉川は、「中立的で、科学技 術他の助言と矛盾しない範囲に留まる調和的な助言」を 提案する。「光のような助言を行う者に対し、社会は信頼 を寄せる」からである。

ここに、吉川のいう「中立的で、社会からの信頼を得 る助言」と、ザイマンのいう「生活世界に有益な信仰と なるアカデミック科学」は内容においてほど袁くないも のであろう。とするなら、まさに「精査と批判」のエト スこ炎が「7 0万人といわれる科学者共同体」に必要な のではなかろうか。弚れか助言機関としてのアカデミー を可能にするであろう。 
基礎研究についても、さまざまなに論じられているが、 兴の一つ文化的活動として位置つけようという議論が ある。例えば、「第3回社会技術研究フォーラム」(2002) では文化としての科学を尊敬するような社会が必要で ある。…具体的にどうするかは更に検討する必要があ る」ことか確認されている ${ }^{48)}$ 。文化という点では、ザイ マン・モデルの科学者達の活動は十分乥うではなかった ろうか。

以上、S T S、科学アカデミー、文化としての科学の 議論の中にザイマン・モデルの展開可能性を確忍した。 具体的な議論の発展は今後の課題としたい。

\section{5 . 終わりに}

本論において、主要なザイマンの科学論を比較検討し、 アカデミック科学モデルの提示と、乥れに基ついたポス ト・アカデミック科学批判の二つに注目した。とくにモ デル中への「科学者共同体の精査と批判」の取り込みに 重要性を認めた。つで、欧米におけるザイマンのモデ ルの受容を確認し、我力国の基礎研究や科学者共同体の 今後のあり方への適用を図った。

本論は、我力国におけるザイマン研究の取りかかりで ある。ザイマン・モデルの精緻化、より具体的なあり方 の提示などについては、十分な検討ができなかったが、 これは筆者を含めたＳT S 研究者、ならびに現場研究者 に与えられた課題と考えたい。

\section{参考文献}

1) ザイマンマン講演「何のための科学か? : 科学の非道具的

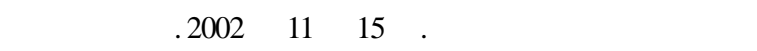
पिए०० . http://www.ristex.jp/english/past.html

2) 三宅苍(2003)「」.ザイマンの科学論／モード 2 科学批判 につて」『科学技術社会論学会第 2 回年次研究大会予稿 集』.pp.13.『リアル・サイエンス』についての考察がな れる。

3) 同樣の傾向は、欧米の科学論にもあてはまるかもしれない。 例えば、Charmers, A. (1985) 『新版 科学論の展開』(高田紀 代志・佐野正博共訳) 恒星社厚生閣 (原著 1982) は、科学 論の流れを広く見渡しているが、ザイマンへの言及はない。

4) 2002 年 11 月、東京にて (八巻俊憲氏のこ厚意による)。

$5)$ Ziman, J. (1976). The Force of Knowledge: The Scientific Dimension of Society. Cambridge: Cambridge University Press. 松井巻之助訳 (1981)『社会における科学』, 草思社 .

6) Ziman, J. (1984) An Introduction to Science Studies, Cambridge: Cambridge University Press.
7) Ziman, J. (1980) Teaching and Learning about Science and Society, Cambridge: Cambridge University Press. . 邦訳 /竹内敬 人・中島秀人 (1988)『科学と社会を結う教育とは』産業図 書

8) Ziman, J. (1987) Knowing Everything about Nothing: Specialization of Change in Scientific Careers, Cambridge: Cambridge University Press.

9) Ziman, J. (1980) Puzzles, Problems and Enigmas: Occasional Pieces on the Human Aspects of Science, Cambridge: Cambridge University Press. ザイマンの講演、エッセーの集成である。

10) Ziman, J. (1995) Of One Mind: The collectivization of Science , N Y:AIP Press. 本書の第5，6章で展開される科学の集合 性についての議論である。

11) Ziman, J. (1968), Public Knowledge: The Social Dimension of Science. Cambridge: Cambridge University Press.

12) 前掲 11). pp.x.

13）しかし、ザイマンとポパーの関係は以外と近いようである。 ザイマンの科学者共同体での組織化された批判には当然ポパ 一の反証可能性も含まれるし、『リアル・サイエンス』では、 科学知識のあるべき世界として、ポパーの第二、第三の世界 を想定している。

14）前掲 11) . pp. 9 .

15）前掲 11).pp. 24 . 興味あることに、三枝博音は、まさに同 じ区別によって、技術の立場から科学と区別している。三 枝博音(1995)『技術思想の探求』こぶし書房. pp.88.（初出 は1939年).

16) クーンの科学革命と政治革命との関連性は、最近のS .フ ラー (Steve Fuller) のクーン論での主要な論点の一つであ る。Fuller, S. (2000) Thomas Kuhn / A Philosophical History of Our Times, Chicago and London.: The University of Chicago Press, pp.318.

17）これらについて前掲 7), 8)を参照のこと。

18) Merton, R. (1961) 『社会理論と社会構造』(森東吾、森好 夫、金沢実、中島竜太郎共訳) みすず書房（原著 1957） pp.491.

19) 前掲 11) . pp. 115 .

20) Ziman J. (1978), Reliable Knowledge: An Explanation of the Grounds for Belief in Science . Cambridge: Cambridge University Press. 邦訳/桜井邦朋 - 大江秀房(1985)『科学 理論 の本 質』地人書館.

21）化学物質による大規模な環境破壊などが光れに該当しよ う。たとえばR .カーソン( 1974)『沈黑の春』(青樹潹一訳) 新潮文庫を参照のこと (原著1962年) .

22）前掲 20) - pp.139 (邦訳)

23）前掲 20) · pp.331 (邦訳)

24）一方、薬師寺は、ポパーの「雲は描けるか」の議論をもと に政策科学を論じた。薬師寺泰蔵(1989)『公共政策』東京 大学出版会. pp.10. 
25) 市川惇信 (2000) 『暴走する科学技術文明』岩波書店. 市川は、演繹・帰納のループを回すことにおいて、科学が 過程的営みだとする。また、市川か犐学知識を八分の一象 限に限っているのも、ザイマンか犐学知識を一つの生活信 仰としているのと類似的である。

26) Ziman, J. (1994) Prometheus Bound: Science in a Dynamic Steady State, Cambridge: Cambridge University Press. 村上陽 一郎・川崎勝・三宅苞共訳(1995)『縛られたプロメテウス /動的定常状態における科学』シュプリンガー・フェアラ 一ク東京.因みに、「プロメテウス」は、ギリシャ神話でチ タン族の英雄で、天上から火を盗んで人間に与えたため天 神ゼウスの怒りを買い、コーカサス山に鎖でつながれる。

27) Gibbons, M. Limoges, C., Nowotony, H., Schwartzman, S., Scott, S., and Trow, M. (1997) 『現代社会と知の創造』(小林信一監 訳) 丸善オブラリー (原著は 1994 年)。

28）例えば、松原隆一郎「信頼の復権」朝日新聞・夕刊 (1997.12/24)、西垣通「モード論への期待」朝日新聞・朝 刊 (1998.1/22) を参照のこと。

29）例えば前掲 27)での日本語版解説で『プロメテウス』は 同じ論点の書として引用されている。pp.11.

30) Ziman, J. (2000) Real Science: What it is and, What it means, 2 . Cambridge: Cambridge University Press.

31）前掲 30). pp. 24.

32) 前掲 30).pp.80.

33）前掲 30). pp.173.

34）前掲 30).pp, 277 .

35) この知識の進化論モデルについては以下を参照のこと。 Ziman, J. (2000) Selection and complexity In Ziman, J. (Ed.), Technological Innovation as an Evolutionary Process (pp.41-51). Cambridge: Cambridge University Press.

36） E.フッサール (1974) 『ヨーロッハ諸学の危機と超越論的 現象学』(訳:細谷恒夫·木田元訳) 中央公論社 (原著は 1954 年) . pp. 174.
37) ザイマン自身、図式化は行っていない。桜井が、前掲 17.299 頁において図式化を行っているが、例えば、科学者自身の 観察がモデル化されていないなど詳細ではない。

38) Hooker, C.A. Science: Legendary, Academic - and Post-Academic?

http://www.newcastle.edu.au/centre/casrg/publications/ZimanRe viewWP5.pdf.

39) Dalgaad, T., Hutchings, N., and Poter, J. Agroecology, scaling and interdisciplinarity. In AGEE 1228

40) Hansen, T., (2003) In ISPY Conference, "Advancing Human Security " Halifax, Nova Scotia.

41) Erno-Kjolhede, E. (2000) Scientific norms as (dis)integrators of scientists? In MPP Working Paper No.14/2000.

42) Sonnert, G. (2002) Ivory Bridges / Connecting Science and Society. Cambridge: The MIT Press.

43) Nowotony, H., Scott, S., and Gibbons, M. (2000) Re Thi nki ng science/Know edge and the Public in an Age of Uncertai nty. Pol ity.

44) 藤村茂 (1999)「科学者のエートス」『専門家集団の思索と 行動』岩波講座 : 科学/技術と人間. pp. 70 .

45) 増田耕一 (2003)「現実の科学」. ht t p: //meb. sf c. kei o. ac.j o/ masudako/r eadi ng/zi nan20 O. ht nh

46)小林傳司偏 (2002)『公共のための科学技術』玉川大学出 版部.

47) 吉川弘之 (2002)『科学者の新しし役割』岩波書店．

48）第3回社会技術研究フォーラム「21 世紀の科学活動/フ オーラム委員と語る基礎研究のこれから」(2002.10.24) http://www.ristex.jp/forum/forum 03.pdf

\section{J. Ziman's Model on Academic Science}

$$
\text { Shigeru MIYAKE }{ }^{1} \text {, }
$$

${ }^{1} \mathrm{Ph} . \mathrm{D}$. (Studies of Science and Technology),

Researcher, Research Institute of Science and Technology for Society (RISTEX)

(E-mail: miyake@ristex.jst.go.jp)

This is one of the earliest works in Japan to introduce Ziman's arguments on science and discuss it. His major books on science studies, i.e., Public Knowledge, Reliable Knowledge, Prometheus Bound, and Real Science are reviewed relatively and his argument of knowledge production in academic science is presented as Ziman' model. The acceptance of Ziman's model in Europe and U.S. are surveyed. Finally, the application of Ziman's model to the arguments of science studies in Japan is discussed.

Key Words: science studies, consensus, scientific community, mode, academic science, knowledge production, ethos, Merton, industrial science. 